Archives of Agriculture and Environmental Science

\title{
Health risk assessment of metals transfer from soil to the edible part of some vegetables grown in Patuakhali province of Bangladesh
}

\author{
Md. Saiful Islam ${ }^{1^{*}}$ (D) , Mst. Salma Khanam² ${ }^{2}$ Nazirul Islam Sarker ${ }^{3}$ \\ ${ }^{1}$ Department of Soil Science, Patuakhali Science and Technology University, Dumki, Patuakhali-8602, BANGLADESH \\ ${ }^{2}$ Department of Agronomy, Patuakhali Science and Technology University, Dumki, Patuakhali-8602, BANGLADESH \\ ${ }^{3}$ School of Public Administration, Sichuan University, Chengdu, CHINA \\ *Corresponding author's E-mail: msaifulpstu@yahoo.com
}

\section{ARTICLE HISTORY}

Received: 13 April 2018

Revised received: 28 May 2018

Accepted: 31 May 2018

\section{Keywords}

Heavy metals

Health risk

Sequential extraction

Soils

Transfer factor

Vegetables

\begin{abstract}
This study was conducted to investigate the contamination and chemical speciation of six heavy metals like $\mathrm{Cr}, \mathrm{Ni}, \mathrm{Cu}, \mathrm{As}, \mathrm{Cd}$ and $\mathrm{Pb}$ in soil, their transfer to the edible parts of vegetables i.e. Brinjal (Solanum melongena), Green amaranth (Amaranthus hybridus), Red amaranth (Amaranthus Gangeticus), Bottle gourd (Lagenaria siceraria), Tomato (Solanum lycopersicum), Pumpkin (Cucurbita maxima), Chili (Capsicum annuum L), Carrot (Daucus carota), Bean (Phaseolus vulgaris), Onion (Allium cepa), Potato (Solanum tuberosum) and Lentil (Lens culinaris). The ranges of heavy metals in soil were 3.7-41, 3.9-36, 7.6-46, 2.3-26, 0.61-13 and 4.5-32 mg/kg for $\mathrm{Cr}, \mathrm{Ni}$, $\mathrm{Cu}, \mathrm{As}, \mathrm{Cd}$ and $\mathrm{Pb}$, respectively. The metals were mainly associated with the residual fractions of $39 \%, 41 \%, 40 \%, 40 \%, 34 \%$ and $41 \%$ for $\mathrm{Cr}$, $\mathrm{Ni}, \mathrm{Cu}, \mathrm{As}, \mathrm{Cd}$ and $\mathrm{Pb}$, respectively. In the edible tissues of vegetables, the concentrations of $\mathrm{As}, \mathrm{Cd}$ and $\mathrm{Pb}$ in most vegetable samples exceeded the maximum permissible levels, indicating not safe for human consumption. Target hazard index $(\mathrm{HI})$ value indicates people would experience health risk due to consumption of vegetables. The carcinogenic risk (TR) of As and $\mathrm{Pb}$ through consumption of vegetables were higher than the USEPA threshold level $\left(10^{-6}\right)$, indicating potential cancer risks.
\end{abstract}

(C)2018 Agriculture and Environmental Science Academy

Citation of this article: Islam, M.S., Khanam, M.S. and Sarker, N.I. (2018). Health risk assessment of metals transfer from soil to the edible part of some vegetables grown in Patuakhali province of Bangladesh. Archives of Agriculture and Environmental Science, 3(2): 187-197, https://dx.doi.org/10.26832/24566632.2018.0302013

\section{INTRODUCTION}

The concentrations of heavy metals and metalloids in agricultural soils are of great concern because of their persistence in the environment, non-biodegradable nature, long biological half -lives and toxicity to humans and other organisms (Radha et al., 1997). Heavy metals and metalloids such as $\mathrm{Cr}, \mathrm{Cu}, \mathrm{Cd}, \mathrm{Pb}$ and As have been considered the most toxic elements in the environment and included in the US Environment Protection Agency (EPA) list of priority pollutants (Lei et al., 2010). The degree at which metals are associated with different chemical forms depends on soil properties such as $\mathrm{pH}$, organic matter content, redox conditions and soil texture (Rieuwerts et al., 2006). In general, under natural conditions, only a small portion of the metals in soils can be available for plants (Kabata-Pendias and Pendias, 1992). Therefore, the total concentration of metals in soils can provide very limited information on their toxic effects (Kashem et al., 2007). Some studies have shown that the toxicity and mobility of heavy metals in soil depend on their specific forms or binding condition (Kashem et al., 2007). Therefore, the geochemical fractionation of heavy metals in soil is necessary to know the fate and behavior of metals in soil.

The accumulation of heavy metals in vegetables may depend on the soil type, plant species, growth condition, the surrounding environment and the presence of other ions. However, the transformation efficiency of metals is measured by soil-plant transfer factors (Rattan et al., 2005). The transfer factor is generally defined as the ratio of metal concentration in plant to the total metal concentration in soil (Cui et al., 2004). The environmental safety of vegetables against pollution is especially 
crucial to human health. A continuous determination of total amounts enables evaluation of possible routes through which food elements are ingested. Thus, elemental concentration assessments in vegetables are very important to risk assessment studies. Vegetables can uptake heavy metals and accumulate them in their edible and inedible parts (Rahman et al., 2013) in quantities high sufficient to cause clinical harms both to the animals and humans consuming these metal-rich plants (Islam et al., 2014a). Therefore, heavy metal contamination in vegetables cannot be taken too lightly as these foodstuffs are important components of human diet. Vegetables are rich sources of vitamins, minerals and fibers and also have beneficial antioxidative effects (Ali and Al-Qahtani, 2012). However, intake of metalcontaminated vegetables may pose a risk to the human health.

Health risks have been evaluated by numerous methods but most commonly, risk to the human health is computed in terms of target hazard quotients (THQs) which is based on the concentration of the metal in edible parts in comparison with the reference dose of the metal and intake/body weight of the consumers, while carcinogenic health risk is assessed by calculating the target cancer risk (TR) (USEPA, 2006, 2010). Concern over the environmental pollutants particularly the toxic heavy metals has increased immensely in Bangladesh during the last few decades in the wake of population explosion, industrialization, urbanization and other human activities (Islam et al., 2015, 2016). Studied vegetables are being used by the local inhabitants on regular basis since long time, but to our knowledge, no systematic investigation has been carried out to find the health risks associated with metal concentration in these vegetables.

The present investigation was, therefore, aimed to assess the chemical speciation of heavy metals in soil, to evaluate the concentrations of heavy metals in commonly consumed vegetables i.e. Brinjal (Solanum melongena), Green amaranth (Amaranthus hybridus), Red amaranth (Amaranthus Gangeticus), Bottle gourd (Lagenaria siceraria), Tomato (Solanum lycopersicum), Pumpkin (Cucurbita maxima), Chili (Capsicum annuum L), Carrot (Daucus carota), Bean (Phaseolus vulgaris), Onion (Allium cepa), Potato (Solanum tuberosum) and Lentil (Lens culinaris) and to estimate the potential non-carcinogenic and carcinogenic health risks of heavy metals for the inhabitants in the study area.

\section{MATERIALS AND METHODS}

\section{Study area}

For present study, the agriculture fields selected besides the Paira River located at the southern part of Bangladesh (Figure 1). The study area is located between latitudes $22^{\circ} 20^{\prime} 49.87^{\prime \prime}$ and $22^{\circ} 27^{\prime} 27.18^{\prime \prime} \mathrm{N}$ and longitudes 90 $90^{\circ} 28.24^{\prime \prime}$ and $90^{\circ} 26^{\prime} 54.68^{\prime \prime} \mathrm{E}$. Most of the treated and untreated industrial effluents have been continuously discharged to the river. Several acres of agricultural lands have been irrigated by river water and farmers cultivate various types of vegetable crops for their economic importance. As per the information given by the local farmers we have identified the above area where river water irrigation has been a common practice for many years. The name of the sampling locations were S1: Chargarabdi, S2: Boga ferrighat, S3: Boga, S4: Big vegetables field, Patuakhali, S5: Ferri ghat, Patuakhali, S6: Patuakhali Sadar, S7 \& S9: Patuakhali launch ghat area, S8: launch new market and S10: Patuakhali and Galachipa connecting point.

\section{Soil and vegetable sampling}

The sampling was conducted in August-September, 2013. The samples were collected from ten vegetable growing fields besides the Paira River of Patuakhali district located at the southern part of Bangladesh. At each sampling station, soil sample (up to $20 \mathrm{~cm}$ ) was collected in the form of sub-samples at a distance of about $20 \mathrm{~m}$ each from the first sub-sample in five different locations. These sub-samples were thoroughly mixed to form a composite sample and each station four composite samples were collected. Twelve different vegetable species i.e. Brinjal (Solanum melongena), Green amaranth (Amaranthus hybridus), Red amaranth (Amaranthus Gangeticus), Bottle gourd (Lagenaria siceraria), Tomato (Solanum lycopersicum), Pumpkin (Cucurbita maxima), Chili (Capsicum annuum L), Carrot (Daucus carota), Bean (Phaseolus vulgaris), Onion (Allium cepa), Potato (Solanum tuberosum) and Lentil (Lens culinaris) were collected from the same sites where the soil samples were collected in the study area during the sampling period. At each sampling site, three to five replicate vegetable samples were randomly collected. Soil samples were air-dried at room temperature, then grounded and homogenized. Each vegetable sample was carefully washed with distilled water and the edible part of vegetables were cut into small pieces and then oven dried at $70-80{ }^{\circ} \mathrm{C}$ to attain constant weight (Tiwari et al. 2011). The moisture contents in vegetables were calculated by recording the fresh and dry weights. The dried soil and vegetable samples were crumbled and pulverized with a porcelain mortar and pestle and sieved through $2 \mathrm{~mm}$ nylon sieve and stored in airtight clean zip lock bag in freezer condition up to chemical analysis was carried out.

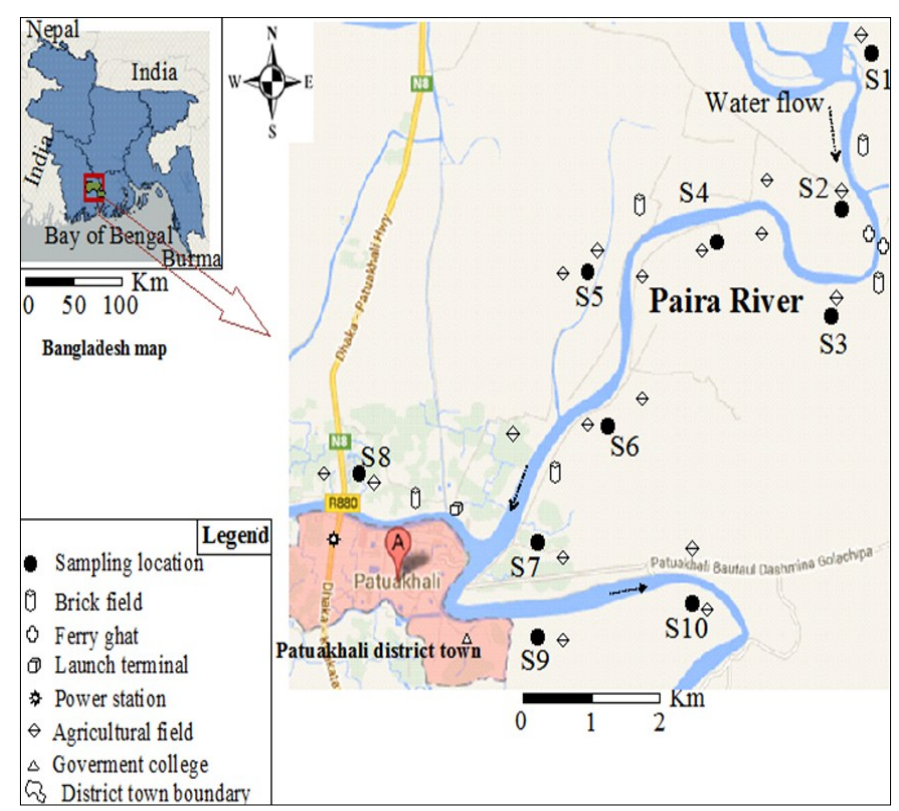

Figure 1. Map of the study area of Patuakhali district in Bangladesh. 


\section{Sample processing}

All chemicals were analytical grade reagents and Milli-Q (Elix UV5 and MilliQ, Millipore, USA) water was used for solution preparation. For total metal analysis, $0.5 \mathrm{~g}$ of the soil sample was treated with $1.5 \mathrm{ml} 69 \% \mathrm{HNO}_{3}$ (Kanto Chemical Co, Japan) and $4.5 \mathrm{ml}$ concentrated $\mathrm{HCl}$ (Kanto Chemical Co, Japan) in a closed Teflon vessel and was digested in a Microwave Digestion System (Berghof speedwave ${ }^{\circledR}$ ). For vegetable, $0.3 \mathrm{~g}$ of dried sample was digested with $6 \mathrm{ml} 69 \% \mathrm{HNO}_{3}$ and $2 \mathrm{ml} \mathrm{30 \%} \mathrm{H}_{2} \mathrm{O}_{2}$ (Wako Chemical Co, Japan) in a Microwave Digestion System. The digested soil and vegetable samples were then transferred into a Teflon

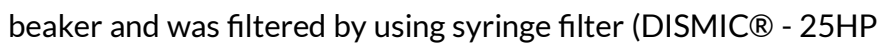
PTTF, pore size $=0.45 \mu \mathrm{m}$ ) Toyo Roshi Kaisha, Ltd., Japan and stored in $50 \mathrm{ml}$ polypropylene tubes (Nalgene, New York).

For chemical partitioning of metals, soil samples were analyzed by using Tessier sequential chemical extraction procedure which helps to evaluate the mobility of metals (Tessier et al., 1979). The sequential extraction procedure was divided into five operationally defined chemical fractions: (F1) the exchangeable fraction: readily soluble and exchangeable; (F2) the carbonate bound and specifically adsorbed fraction: carbonatebound, specifically adsorbed and weak organic and inorganic complexes; (F3) the Fe-Mn oxides fraction: bound to iron and manganese oxides (Fe-Mn oxides); (F4) the organic/sulphide fraction: bound to stable organic and/or sulphide (organic) complexes; and (F5) the residual fraction: held in primary and secondary minerals within their crystal structure.

Instrumental analysis and quality assurance

For trace metals, samples were analyzed by using inductively coupled plasma mass spectrometer (ICP-MS). Multi-element Standard XSTC-13 (Spex CertiPrep ${ }^{\circledR}$ USA) solutions was used to prepare calibration curve. The calibration curves with $\mathrm{R}^{2}>$ 0.999 were accepted for concentration calculation. Working standards were prepared daily in $5 \%(\mathrm{v} / \mathrm{v}) \mathrm{HNO}_{3}$ at $69 \%$ ultrapure grade and were used. Multielement standard solution (Agilent Technologies, USA) $1.0 \mathrm{\mu g} / \mathrm{L}$ was used as tuning solution covering a wide range of masses of elements. For each experiment, a run included blank, certified reference materials (CRM) and samples were analyzed in duplicate to eliminate any batch-specific error. Before starting the analysis sequence, relative standard deviation (RSD, $<5 \%$ ) was checked by using tuning solution purchased from the Agilent Technologies.

Estimation of metals transfer factor from soil to vegetables The transfer factor (TF) of metals from soil to the edible parts of a vegetable was defined as the ratio of the metal concentration in the plant's tissues to the metal concentration in soil and was calculated as follows:

$$
T F=\frac{C_{\text {plant }}}{C_{\text {soil }}}
$$

Where, $C_{\text {plant }}$ and $C_{\text {soil }}$ represent the total trace metal concentration in the edible part of vegetables and total or fractionated metal concentration in soils on a dry weight basis, respectively (Khan et al., 2010; Li et al., 2012).

\section{Health risk assessment}

\section{Estimated daily intake (EDI) of metal}

The estimated daily intakes (EDIs) of selected heavy metals (mg/ day) were calculated using their respective average concentration in vegetables by the weight of food items consumed by an individual (body weight $60 \mathrm{~kg}$ for an adult in Bangladesh) (FAO, 2006), which was obtained from the household income and expenditure survey (HIES, 2011; Islam et al., 2014a; Shaheen et al., 2016) and calculated by the following formula:

$$
E D I=\frac{F I R \times C}{B W}
$$

Where, FIR is the vegetable intake rate (g/person/day), $\mathrm{C}$ is the concentration of heavy metals in vegetables $[\mathrm{mg} / \mathrm{kg}$, fresh weight (fw)], BW is the body weight assuming $60 \mathrm{~kg}$ for adult residents in the present study.

\section{Non-carcinogenic and carcinogenic risk assessment}

The non-carcinogenic risk for selected metal through vegetables consumption were calculated by the target hazard quotient (THQ) (USEPA, 1989), which is "the ratio of a single substance exposure level over a specified time period (e.g., sub-chronic) to a reference dose (RfD) for that substance derived from a similar exposure period". The equation used for estimating the target hazard quotient is as follows:

$$
T H Q=\frac{E F r \times E D \times F I R \times C}{R f D \times B W \times A T}
$$

$\mathrm{TTHQ}$ (Individual vegetable) $=\mathrm{THQ}$ toxicant $1+\mathrm{THQ}$ toxicant $2+\ldots$ $+\mathrm{THQ}_{\text {toxicant }}$

Where, T in the expression "TTHO" means total. In order to assess the overall potential for non-carcinogenic effects from more than one heavy metal, a hazard index (HI) has been formulated based on the Guidelines for Health Risk assessment of Chemical Mixtures of USEPA (1989) as follows:

$$
\begin{aligned}
& \mathrm{HI}=\sum \mathrm{TTHQ}=\mathrm{TTHQ} \text { vegetable } 1+\mathrm{TTHQ} \text { vegetable } 2+\ldots . .+\mathrm{TTHQ} \\
& \text { vegetablen }
\end{aligned}
$$

Where, THQ is defined as the the target hazard quotient; EFr is the exposure frequency (365 days/year); ED is the exposure duration (70 years); FIR is the vegetables intake rate $(170.04 \mathrm{~g} /$ person/day) (Islam et al., 2014a,b); $C$ is the metal concentration in vegetables (mg/kg fw); RfD is the oral reference dose $(\mathrm{mg} / \mathrm{kg} /$ day); AT is the averaging time for non-carcinogens (365 days/ year $\times$ number of exposure years). The oral reference doses were based on 1.5, 0.02, 0.04, 0.0003, 0.0005 and $0.004 \mathrm{mg} / \mathrm{kg} /$ day for $\mathrm{Cr}, \mathrm{Ni}, \mathrm{Cu}, \mathrm{As}, \mathrm{Cd}$ and $\mathrm{Pb}$, respectively (USEPA, 2010; Islam et al., 2014b). If the THQ is less than 1, the exposed population is unlikely to experience obvious adverse effects. If 
the THQ is equal to or higher than 1, there is a potential health risk and related interventions and protective measurements should be taken.

The equation used for estimating the target carcinogenic risk factor (lifetime cancer risk) (USEPA, 1989) is as follows:

$$
T R=\frac{E F r \times E D \times F I R \times C \times C S F O}{B W \times A T} \times 10^{-3}
$$

Where, TR represents target cancer risk or the risk of cancer over a lifetime; $A T$ is the averaging time for carcinogens (365 days/year $\times E D$ ); CSFo is the oral carcinogenic slope factor from the Integrated Risk Information System USEPA (2010) database. It is 1.5 and $8.5 \times 10^{-3}(\mathrm{mg} / \mathrm{kg} / \text { day })^{-1}$ for $\mathrm{As}$ and $\mathrm{Pb}$, respectively.

\section{Statistical analysis}

The data were statistically analyzed using the statistical package, SPSS 16.0 (SPSS, USA). The means and standard deviations of the metal concentrations in soil and vegetables were calculated. Multivariate Post Hoc Tukey tests were employed to examine the statistical significance in the differences of mean concentrations of heavy metals among vegetables and sites.

\section{RESULTS AND DISCUSSION}

\section{Metal contamination in soil}

The concentration of various heavy metals $(\mathrm{Cr}, \mathrm{Ni}, \mathrm{Cu}, \mathrm{As}, \mathrm{Cd}$ and $\mathrm{Pb}$ ) in different soil samples of the study area are presented in Table 1. The average concentration of total heavy metals in soils were in the following decreasing order of $\mathrm{Cr}>\mathrm{Ni}>\mathrm{Cu}>\mathrm{Pb}$ $>\mathrm{As}>\mathrm{Cd}$. The highest mean concentration of $\mathrm{Cr}(33 \mathrm{mg} / \mathrm{kg}), \mathrm{Ni}$ (30 mg/kg) and $\mathrm{Pb}(29 \mathrm{mg} / \mathrm{kg})$ were found at S5 site, and $\mathrm{Cu}(29$ $\mathrm{mg} / \mathrm{kg}$ ) at S1 site, As (14 mg/kg), Cd (9.4 mg/kg) at S7 site, respectively (Table 1 ). High levels of these elements were observed at S1, S5 and S7 sites, due to the effects of brick kiln and the activities from the district town. There were significant differences for metals content in soil among the sampling sites. According to our evaluation, $\mathrm{Cr}$ showed the highest values followed by $\mathrm{Ni}$, amongst the heavy metals reported in this study. This finding can be ascribed to the fact that chromium salts are the most widely used as tanning substances (Kabata-Pendias 2001).

The highest concentration of $\mathrm{Cd}$ was obtained at $9.4 \mathrm{mg} / \mathrm{kg}$ at S7 site, which is mostly used for making paints, batteries and catalyst of this site. During our sampling campaign, we observed leachates from defused $\mathrm{Ni}-\mathrm{Cd}$ batteries, $\mathrm{Cd}$ plated items, casting lead and lead products manufacturing of Patuakhali district town at S7 site. Used metal fittings, rubber, plastics, tires, paints, etc. are materials emitting $\mathrm{Cd}$ to the environment (Hossain et al., 2007). One of the previous studies conducted in Bangladesh, mean soil concentrations of $\mathrm{Pb}, \mathrm{Ni}$, and $\mathrm{Cd}$ in the vicinity of textile industries were found to be $56.4,51.1$, and $164 \mathrm{mg} / \mathrm{kg}$, respectively (Kashem and Singh, 1999). The mean concentration of Cd was higher than Dutch Target Value, Canadian Environmental Quality Guidelines and department of Environmental
Protection, Australia (Table 2). It seems that the pollution of $\mathrm{Cd}$ in soil is the most serious among the studied metals. The soil was contaminated with $\mathrm{Cd}$ through the repeated use of polluted water from the river, application of chemical fertilizers and pesticides (Ahmad and Gani, 2010). In comparison with the maximum permissible concentration of metals for agricultural soil and some other study from Bangladesh and other countries near the industrial area indicated that soils were contaminated by $\mathrm{As}, \mathrm{Cd}$ and $\mathrm{Pb}$ (Table 2). However, these soils might pose severe contamination due to the frequent use of contaminated river water and untreated waste from the town for crop production. With regard to agricultural soil, the major inputs of heavy metals are the application of agrochemicals and other soil amendments (Wong et al., 2002).

\section{Geochemical speciation of metals in soil}

The relative distribution of trace metals in different fractions are shown in (Figure 2). In general, the results indicated that studied metals were predominantly associated with the residual fraction followed by the organically bound phases. These two fractions accounted for more than (44-79\%), (56-77\%), (5077\%), (44-72\%), (41-77\%) and (50-75\%) for $\mathrm{Cr}, \mathrm{Ni}, \mathrm{Cu}, \mathrm{As}, \mathrm{Cd}$ and $\mathrm{Pb}$, respectively of the total concentrations in soil (Figure 2). In this study, the residual phase is believed to consist mainly of primary and secondary minerals, which hold metals within their crystalline structure (Szolnoki and Farsang, 2013). Considering the average percentage of exchangeable and carbonate bound fraction, Cd was significantly higher than the other metals, implying that $\mathrm{Cd}$ is more mobile and phytoavailable. In the case of $\mathrm{Cu}$, in addition to the reducible fraction, the oxidisable fraction (coinciding with organic matter and sulphides) was also noticeable ( $21 \%$ of the total content). This agrees with the results obtained by several authors (Morillo et al., 2004; Wang et al., 1998) found high proportions of $\mathrm{Cu}$ in the oxidisable fraction due to the high stability of the organic Cu complexes. As for $\mathrm{Cr}, \mathrm{Ni}, \mathrm{Cu}, \mathrm{As}, \mathrm{Cd}$ and $\mathrm{Pb}$, in the soil of the studied fields, they were mainly bound to the residual fraction, followed by the FeMn oxides or organically bound phases (Figure 2). This result suggested that under the aerobic conditions and acidic to neutral $\mathrm{pH}$ condition, $\mathrm{Cr}, \mathrm{Ni}$ and $\mathrm{Pb}$ can make complex form with organic ligands, oxides, and clay content in soil. In the present study, relative distribution of $\mathrm{Pb}$ in soil samples were (2.4-9.0\%), (7.1-21\%), (9.4-26\%), (19-31\%) and (31-50\%) for exchangeable, carbonates, Fe-Mn oxides, organic and residual fraction, respectively (Figure 2 ).

\section{Metal contamination in vegetables}

The concentrations of heavy metals $(\mathrm{mg} / \mathrm{kg} \mathrm{fw}$ ) in the edible parts of vegetables are summarized in Table 3 . The average concentration of heavy metals among the vegetables showed the following descending order of $A$. hybridus $>A$. Gangeticus $>L$. siceraria $>$ S. melongena $>$ C. annuum $>$ C. maxima $>$ L. culinaris $>S$. tuberosum $>P$. vulgaris $>D$. carota $>A$. cepa $>S$. lycopersicum. Considering the food safety standards, As, $\mathrm{Cd}$ and $\mathrm{Pb}$ content in all vegetables was higher than the recommended permissible 
level (Table 3), indicating unsafe for human consumption. Among the studied vegetables, green amaranth (A. hybridus) accumulated much higher amounts of trace metals (1.3, 3.2, 2.9, 0.15, 0.32 and $1.2 \mathrm{mg} / \mathrm{kg}$ fw for $\mathrm{Cr}, \mathrm{Ni}, \mathrm{Cu}, \mathrm{As}, \mathrm{Cd}$ and $\mathrm{Pb}$, respectively) than the other vegetables. Among the vegetables, the highest mean concentration of $\mathrm{Pb}$ was found in A. hybridus (1.2 mg/kg fw) and the lowest content of $\mathrm{Pb}$ was obtained in C. annuum $(0.10 \mathrm{mg} / \mathrm{kg}$ $\mathrm{fw}$ ) (Table 3). A major pathway for $\mathrm{Pb}$ may enter the aboveground tissues of plants is through foliar deposition ( $\mathrm{Xu}$ et al., 2013). Our observations revealed pronounced $\mathrm{Pb}$ concentration in vegetables at S3, S6, S7 and S9 sites. Burning activities of industrial waste, coal in the brick fields and dense traffic activities were observed at these sites, which might result to the deposition of particulate matter (PM) on vegetables. Thus, the vegetables were exposed to fine particles of lead containing $\mathrm{PbSO}_{4}, \mathrm{PbO}$ and $\mathrm{PbCO}_{3}$. Uzu et al. (2011) showed that PM deposited on plant leaves and penetrate inside the plant tissues.

Transfer of metals from soil to vegetables

As seen from Figure 3, large variations in transfer factor (TFs) were observed among different vegetables and metals. The average TF of trace metals in all crops were in the descending order of $\mathrm{Cu}>\mathrm{Ni}>\mathrm{Cr}>\mathrm{Pb}>\mathrm{As}>\mathrm{Cd}$. The TF values for $\mathrm{Cu}$ varied from 0.96 to 2.5 , with a mean of 1.7 , which was the highest among the selected six metals. Considering the TF of metals in vegetables, the highest TF was observed in A. hybridus (0.98) and the lowest was observed in A. cepa (0.42). The transfer factor for the studied vegetables, $\mathrm{Cr}, \mathrm{Ni}$ and $\mathrm{Cu}$ showed slight variation whereas, TF varied notably for $\mathrm{As}, \mathrm{Cd}$ and $\mathrm{Pb}$ (Figure 3). Generally, the TF of heavy metals is controlled by the chemical speciation of trace metals in soil, soil properties, such as $\mathrm{pH}$ and salinity and crop genetic features (Peris et al., 2007).

The transfer of metals from soil to vegetables is thought to decrease approximately in the order of the extraction sequence, from readily available to unavailable, because the strength of extraction reagents used increases in this sequence (Tessier and Campbell, 1987). Hence, the exchangeable fraction may indicate the form of the metals that are most transferable from soil to vegetables. Translocation of metal ions from soil to plants is mainly controlled by the root cell wall, the ion transmembrane transport in the endoderm cytoplasma membrane and the water transport in the xylem vessel (Li et al., 2012). Considering the exchangeable fraction, $\mathrm{Cu}$ was the highest among the studied six metals resulting in high TF (Figure 3). The present study showed that, a considerable proportion of $\mathrm{Cu}$ was observed in the loosely bound fraction (exchangeable and carbonates), which facilitate higher metal transfer in vegetables.

Health risk assessment due to daily intake of heavy metals The dietary exposure approach of heavy metals of vegetables consumption is a reliable tool for investigating a population's diet in terms of intake levels of nutrients, bioactive compounds and contaminants, providing important information about the potential nutritional deficiencies or exposure to food contami- nants (WHO, 1985). The EDI of Cr, Ni, Cu, Zn, As, Cd and Pb were evaluated according to the mean concentration of each metal in each species of vegetable and the respective consumption rate for each species of vegetable (Santos et al., 2004). The EDI of the studied metals from consumption of vegetables are shown in Table 4. In vegetable samples, mean values of EDI showed the same descending order of $\mathrm{Ni}>\mathrm{Cr}>\mathrm{Pb}>\mathrm{Cd}>\mathrm{Cu}>\mathrm{As}$. Total daily intake of $\mathrm{Cr}, \mathrm{Ni}, \mathrm{Cu}, \mathrm{As}, \mathrm{Cd}$ and $\mathrm{Pb}$ were 1.751, 2.157, 0.198, $0.096,0.466$ and $1.751 \mathrm{mg} /$ day, respectively. The total EDI of the studied metals (except $\mathrm{Cu}$ and $\mathrm{As}$ ) through consumption of vegetables were higher than the maximum tolerable daily intake (MTDI) (Table 4), indicated that these vegetables might pose risk to the consumers in the study area, Bangladesh.

\section{Non-carcinogenic and carcinogenic risk}

The target hazard quotient (THQ) for non-carcinogenic risk and target carcinogenic risk (TR) of the six studied metals from consuming vegetables for adults inhabitants are presented in Table 5. The THQ value for individual metal (except some species of As) in vegetable was less than unity, which is considered as safe for human consumption. Total THQ values of the studied metals from vegetables (except C. annuum, A. cepa and $S$. tuberosum) were higher than 1 , indicated that if people consume these types of vegetables in their diet, they might be at risk. Arsenic and $\mathrm{Cd}$ exhibited relatively higher THQ compared to all other metals in the study area. Among the selected vegetable species the highest total THQ was observed for L. siceraria (4.386) followed by the S. lycopersicum (2.109) (Table 5) indicating potential non-carcinogenic risks. The total metal THQ value [(sum of individual metal THQ (HI)] i.e. due to consumption of vegetables in the study area was $18.514(>1)$. Potential health risks from exposure to vegetables are therefore of great concern. The analysis of non-carcinogenic health hazards resulting from exposure to metals through vegetables intake indicated that the investigated vegetables were not safe for human consumption (Table 5).

Due to the lack of oral slope factor of $\mathrm{Cd}$, target carcinogenic risks (TR) derived from the intake of $\mathrm{As}$ and $\mathrm{Pb}$ through the consumption of different vegetables are listed in Table 5. The TR values for As ranged from 0.024 to 0.830 and 0.0001 to 0.017 for $\mathrm{Pb}$ which were higher than the acceptable risk limit (0.000001) (USEPA, 2010) indicating that the inhabitants consuming these vegetables are exposed to $\mathrm{As}$ and $\mathrm{Pb}$ with $\mathrm{a}$ lifetime cancer risk. The percentage of inorganic As depend on the types of food. For instance, in fish, the percentage of inorganic As is only up to $11 \%$, whereas in food commodities other than fish and seafood, it is assumed to vary from 50 to 100 $\%$ of the total arsenic (EFSA, 2006). If we assume $50 \%$ of the total arsenic as inorganic As (Saha and Zaman, 2013) then carcinogenic risk through the consumption of vegetable is reduced. If the whole intake of metals through dietary means (vegetables and other foods) would be taken into account, the potential health risks involved in the consumption of local food should not be ignored. 

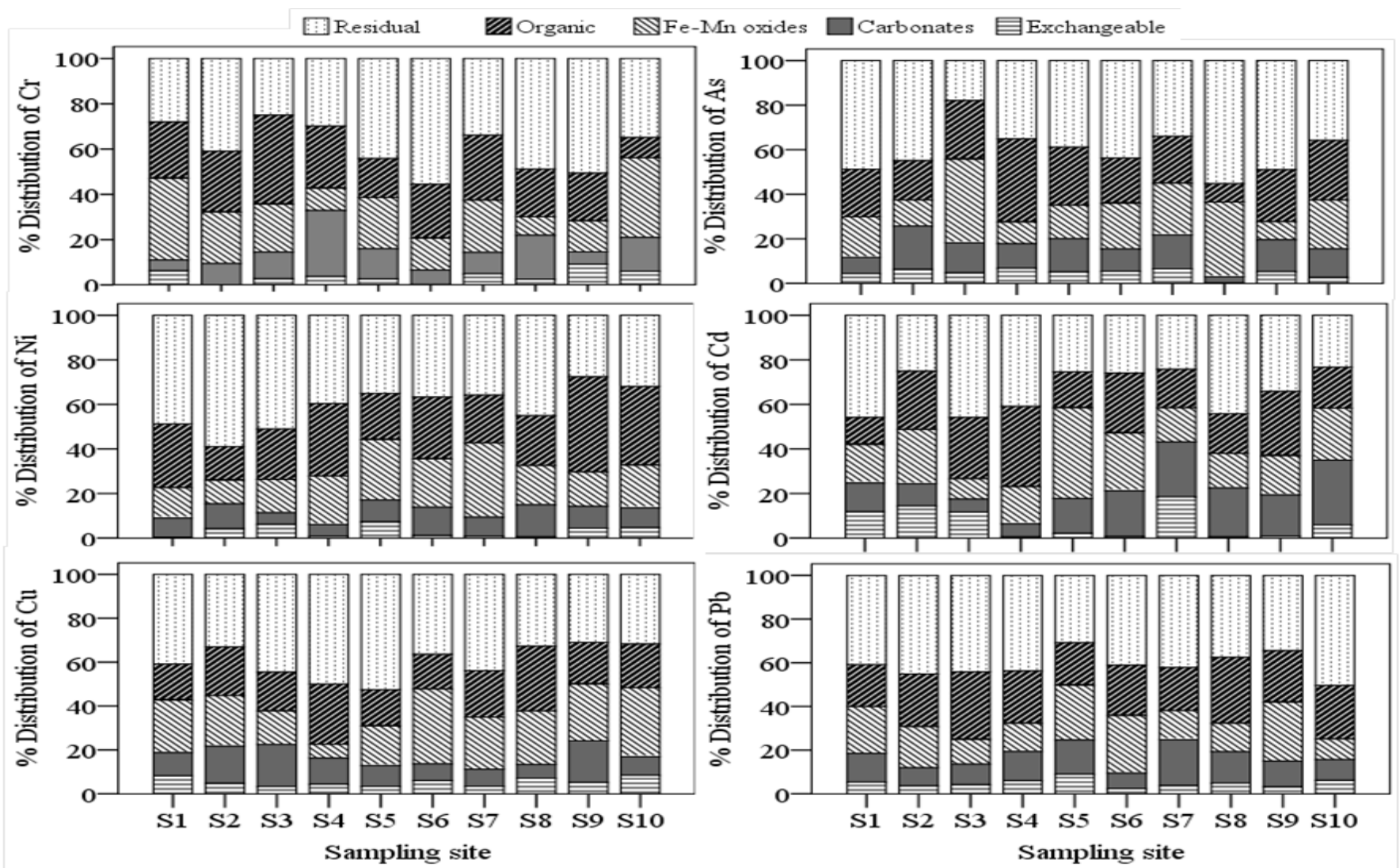

Figure 2. Relative distribution of heavy metals in soil at different geochemical fractions.

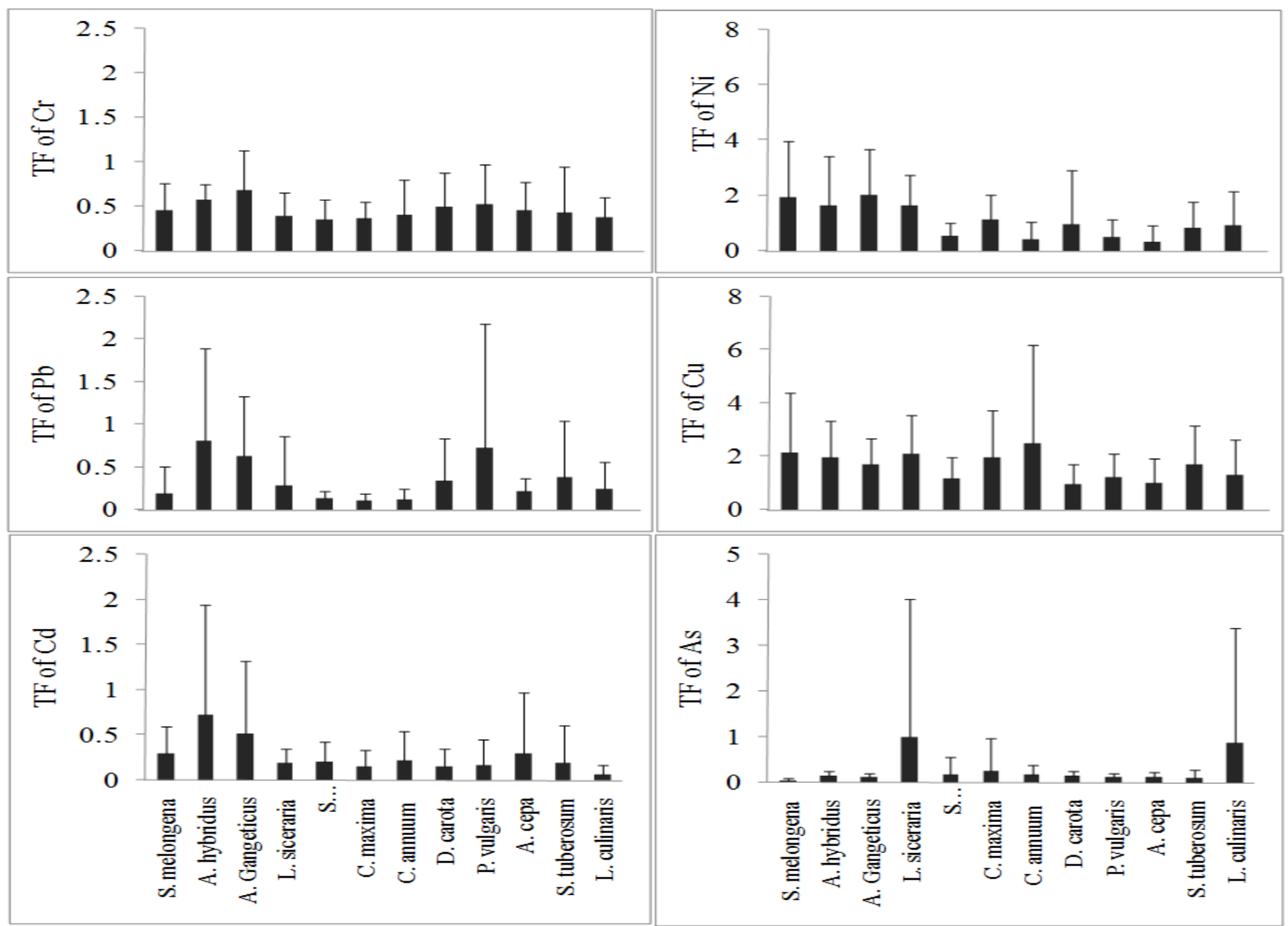

Figure 3. Transfer factor (TF) of metals in vegetables of the study area in Bangladesh. 


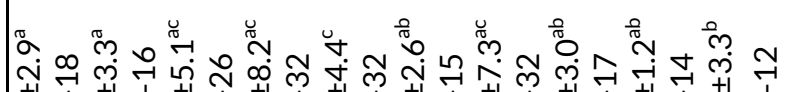

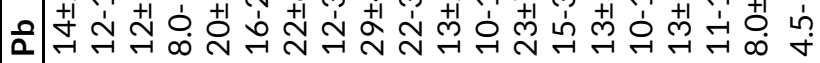

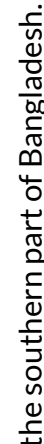

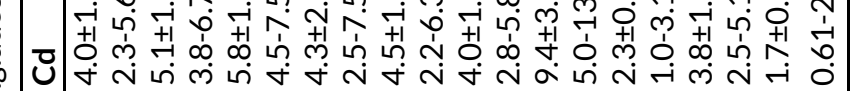

西

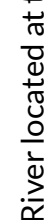

\section{. \\ $\frac{\sqrt{\pi}}{2}$}

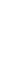

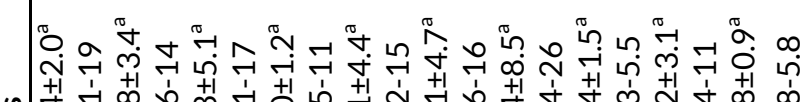

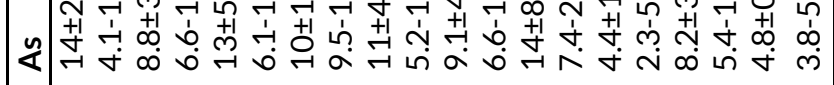

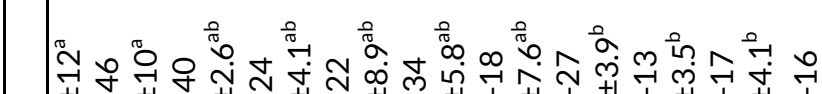

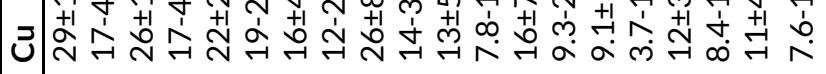

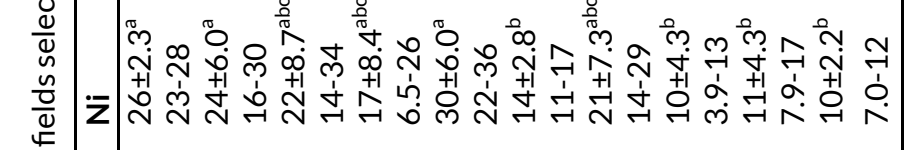

.

พิ๊

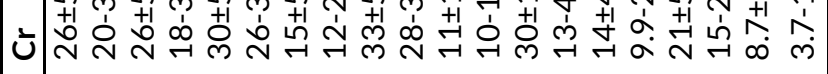

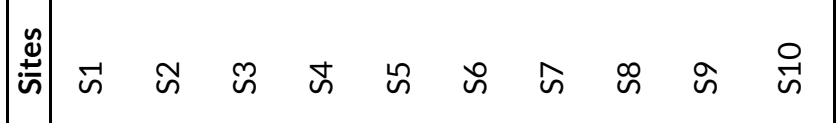

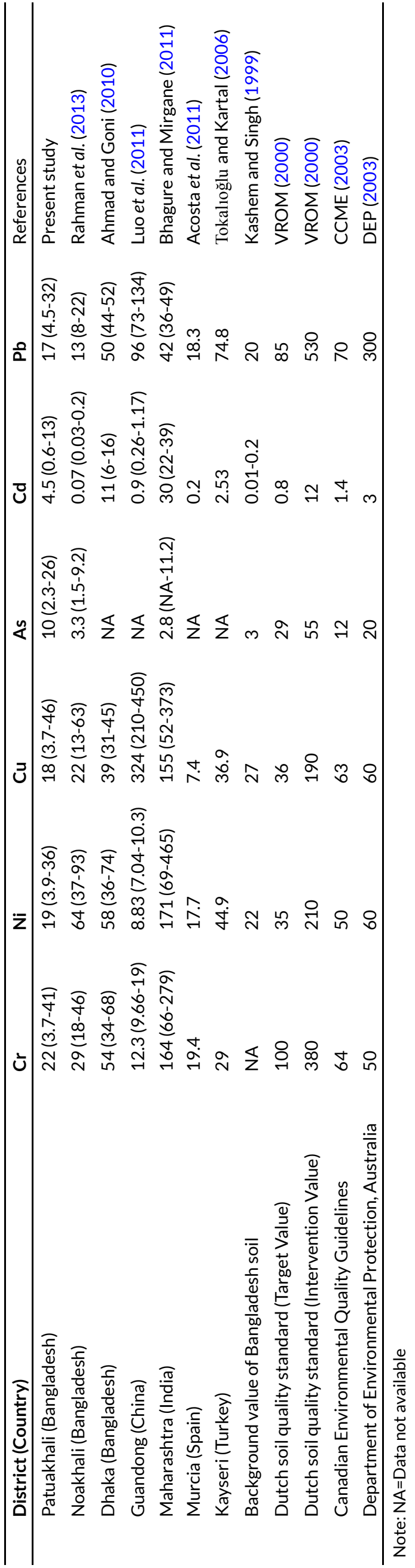


Table 3. Metal concentration ( $\mathrm{mg} / \mathrm{kg} \mathrm{fw}$ ) in vegetables of the present study in Bangladesh.

\begin{tabular}{|c|c|c|c|c|c|c|c|c|}
\hline Common name & Scientific name & & $\mathrm{Cr}$ & $\mathrm{Ni}$ & $\mathrm{Cu}$ & As & $\mathrm{Cd}$ & $\mathrm{Pb}$ \\
\hline \multirow{2}{*}{ Brinjal } & \multirow{2}{*}{ Solanum melongena } & Mean \pm SD & $0.83 \pm 0.44$ & $2.8 \pm 2.3$ & $2.8 \pm 2.1$ & $0.04 \pm 0.04$ & $0.11 \pm 0.11$ & $0.28 \pm 0.41$ \\
\hline & & Range & $0.44-1.9$ & $0.13-6.2$ & $0.27-6.1$ & $0.01-0.15$ & $0.002-0.28$ & $0.04-1.4$ \\
\hline \multirow{2}{*}{ Green amaranth } & \multirow{2}{*}{ Amaranthus hybridus } & Mean \pm SD & $1.3 \pm 0.67$ & $3.2 \pm 4.0$ & $2.9 \pm 1.5$ & $0.15 \pm 0.11$ & $0.32 \pm 0.46$ & $1.2 \pm 1.3$ \\
\hline & & Range & $0.49-2.4$ & $0.34-12$ & $0.86-5.8$ & $0.01-0.40$ & $0.01-1.6$ & $0.07-4.5$ \\
\hline \multirow[t]{2}{*}{ Red amaranth } & Amaranthus Gangeticus L & Mean \pm SD & $1.5 \pm 1.3$ & $3.6 \pm 2.9$ & $2.6 \pm 1.1$ & $0.12 \pm 0.11$ & $0.25 \pm 0.32$ & $0.97 \pm 0.89$ \\
\hline & & Range & $0.41-3.9$ & $0.12-8.5$ & $1.1-4.5$ & $0.013-0.32$ & $0.003-0.99$ & $0.04-3.0$ \\
\hline \multirow[t]{2}{*}{ Bottle gourd } & Lagenaria siceraria & Mean \pm SD & $0.67 \pm 0.26$ & $3.2 \pm 2.2$ & $3.2 \pm 1.5$ & $0.83 \pm 2.5$ & $0.09 \pm 0.09$ & $0.41 \pm 0.74$ \\
\hline & & Range & $0.41-1.1$ & $0.09-7.9$ & $0.64-5.3$ & $0.014-7.9$ & $0.003-0.28$ & $0.04-2.5$ \\
\hline \multirow[t]{2}{*}{ Tomato } & Solanum lycopersicum & Mean \pm SD & $0.63 \pm 0.20$ & $0.81 \pm 0.67$ & $1.6 \pm 0.80$ & $0.21 \pm 0.51$ & $0.07 \pm 0.07$ & $0.21 \pm 0.18$ \\
\hline & & Range & $0.33-0.87$ & $0.08-2.1$ & $0.46-2.4$ & $0.012-1.7$ & $0.001-0.16$ & $0.03-0.62$ \\
\hline \multirow[t]{2}{*}{ Pumpkin } & Cucurbita maxima & Mean \pm SD & $0.67 \pm 0.15$ & $2.1 \pm 1.8$ & $2.7 \pm 1.9$ & $0.22 \pm 0.58$ & $0.06 \pm 0.07$ & $0.20 \pm 0.16$ \\
\hline & & Range & $0.47-0.93$ & $0.11-4.9$ & $0.49-5.8$ & $0.01-1.9$ & 0.004-0.19 & $0.05-0.57$ \\
\hline \multirow[t]{2}{*}{ Chili } & Capsicum annuum L & Mean \pm SD & $0.66 \pm 0.30$ & $0.73 \pm 1.1$ & $5.0 \pm 9.7$ & $0.18 \pm 0.20$ & $0.10 \pm 0.14$ & $0.17 \pm 0.16$ \\
\hline & & Range & $0.27-1.2$ & $0.05-3.2$ & $0.73-32$ & $0.014-0.48$ & $0.001-0.39$ & $0.03-0.52$ \\
\hline \multirow[t]{2}{*}{ Carrot } & Daucus carota & Mean \pm SD & $0.82 \pm 0.32$ & $1.5 \pm 2.8$ & $1.5 \pm 1.1$ & $0.14 \pm 0.09$ & $0.06 \pm 0.09$ & $0.52 \pm 0.71$ \\
\hline & & Range & $0.27-1.2$ & $0.08-8.7$ & $0.25-3.2$ & $0.03-0.28$ & $0.001-0.25$ & $0.05-2.2$ \\
\hline \multirow[t]{2}{*}{ Bean } & Phaseolus vulgaris & Mean \pm SD & $0.82 \pm 0.31$ & $0.89 \pm 1.0$ & $2.1 \pm 1.6$ & $0.11 \pm 0.06$ & $0.08 \pm 0.12$ & $0.95 \pm 1.9$ \\
\hline & & Range & $0.42-1.3$ & $0.02-2.9$ & $0.54-4.9$ & $0.022-0.20$ & $0.003-0.38$ & $0.04-0.63$ \\
\hline \multirow[t]{2}{*}{ Onion } & Allium cepa & Mean \pm SD & $0.80 \pm 0.23$ & $0.66 \pm 1.2$ & $1.7 \pm 1.6$ & $0.10 \pm 0.05$ & $0.15 \pm 0.34$ & $0.37 \pm 0.35$ \\
\hline & & Range & $0.54-1.2$ & $0.05-3.9$ & $0.41-5.0$ & $0.018-0.21$ & $0.002-1.1$ & $0.10-1.3$ \\
\hline \multirow[t]{2}{*}{ Potato } & Solanum tuberosum & Mean \pm SD & $0.68 \pm 0.37$ & $1.3 \pm 1.4$ & $2.4 \pm 1.8$ & $0.07 \pm 0.07$ & $0.10 \pm 0.22$ & $0.43 \pm 0.67$ \\
\hline & & Range & $0.34-1.6$ & $0.07-4.5$ & $0.25-5.8$ & $0.01-0.22$ & $0.002-0.71$ & $0.04-2.0$ \\
\hline \multirow[t]{2}{*}{ Lentil } & Lens culinaris & Mean \pm SD & $0.68 \pm 0.17$ & $1.7 \pm 2.3$ & $1.9 \pm 1.8$ & $0.75 \pm 2.2$ & $0.03 \pm 0.04$ & $0.31 \pm 0.31$ \\
\hline & & Range & $0.48-1.0$ & $0.06-7.0$ & $0.40-6.0$ & $0.02-7.1$ & $0.002-0.13$ & $0.04-0.86$ \\
\hline \multicolumn{3}{|c|}{ Chinese standard for metals in vegetables (Li et al., 2012) } & 0.5 & 0.3 & 10 & NA & 0.05 & 0.1 \\
\hline \multicolumn{3}{|c|}{ Permissible levels as per (FAO and WHO, 2011) } & 2.3 & 10 & 40 & 0.1 & 0.05 & 0.1 \\
\hline
\end{tabular}

Table 4. Estimated daily intakes of heavy metals ( $\mathrm{mg} / \mathrm{day}$ ) from consumption of vegetable species by Bangladeshi adult population.

\begin{tabular}{llllllll}
\hline Vegetables species & Consumption rate (g/day/person) & $\mathrm{Cr}$ & $\mathrm{Ni}$ & $\mathrm{Cu}$ & $\mathrm{As}$ & $\mathrm{Cd}$ & $\mathrm{Pb}$ \\
\hline S. melongena & 130 & 0.108 & 0.364 & 0.364 & 0.005 & 0.014 & 0.036 \\
A. hybridus & 50 & 0.065 & 0.160 & 0.145 & 0.008 & 0.016 & 0.060 \\
A. gangeticus & 50 & 0.075 & 0.180 & 0.130 & 0.006 & 0.013 & 0.049 \\
L. siceraria & 80 & 0.054 & 0.256 & 0.256 & 0.066 & 0.007 & 0.033 \\
S. lycopersicum & 130 & 0.082 & 0.105 & 0.208 & 0.027 & 0.009 & 0.027 \\
C. maxima & 100 & 0.067 & 0.210 & 0.270 & 0.022 & 0.006 & 0.020 \\
C. annuum & 10.5 & 0.007 & 0.008 & 0.053 & 0.002 & 0.001 & 0.002 \\
D. carota & 130 & 0.107 & 0.195 & 0.195 & 0.018 & 0.008 & 0.068 \\
P. vulgaris & 130 & 0.107 & 0.116 & 0.273 & 0.014 & 0.010 & 0.124 \\
A. cepa & 22 & 0.018 & 0.015 & 0.037 & 0.002 & 0.003 & 0.008 \\
S. tuberosum & 70.3 & 0.048 & 0.091 & 0.169 & 0.005 & 0.007 & 0.030 \\
L. culinaris & 30 & 0.020 & 0.051 & 0.057 & 0.023 & 0.001 & 0.009 \\
Total intake from vegetables & & 1.751 & 2.157 & 0.198 & 0.096 & 0.466 & 1.751 \\
Maximum tolerable daily intake (MTDI) & & $0.20^{\mathrm{a}}$ & $0.30^{\mathrm{b}}$ & $30^{c}$ & $0.126^{c}$ & $0.046^{c}$ & $0.21^{c}$ \\
\hline
\end{tabular}

${ }^{\mathrm{a}} \mathrm{RDA}, 1989 ;{ }^{\mathrm{b}} \mathrm{WHO}, 1996 ;{ }^{\mathrm{c} J E C F A}, 2000$

Table 5. Target hazard quotient and target carcinogenic risks due to heavy metals exposure from vegetables species.

\begin{tabular}{|c|c|c|c|c|c|c|c|c|c|}
\hline \multirow[t]{2}{*}{ Species } & \multicolumn{7}{|c|}{ Target hazard quotients (THQs) } & \multicolumn{2}{|c|}{ Target carcinogenic risk (TR) } \\
\hline & $\mathrm{Cr}$ & $\mathrm{Ni}$ & $\mathrm{Cu}$ & As & $\mathrm{Cd}$ & $\mathrm{Pb}$ & Total & As* & $\mathrm{Pb}$ \\
\hline S. melongena & 0.001 & 0.303 & 0.152 & 0.289 & 0.477 & 0.152 & 1.373 & 0.065 & 0.005 \\
\hline A. hybridus & 0.001 & 0.133 & 0.060 & 0.417 & 0.533 & 0.250 & 1.394 & 0.094 & 0.009 \\
\hline A. gangeticus & 0.001 & 0.150 & 0.054 & 0.333 & 0.417 & 0.202 & 1.157 & 0.075 & 0.007 \\
\hline L. siceraria & 0.001 & 0.213 & 0.107 & 3.689 & 0.240 & 0.137 & 4.386 & 0.830 & 0.005 \\
\hline S. lycopersicum & 0.001 & 0.088 & 0.087 & 1.517 & 0.303 & 0.114 & 2.109 & 0.341 & 0.004 \\
\hline C. maxima & 0.001 & 0.175 & 0.113 & 1.222 & 0.200 & 0.083 & 1.794 & 0.275 & 0.003 \\
\hline C. annuum & 0.0001 & 0.006 & 0.022 & 0.105 & 0.035 & 0.007 & 0.176 & 0.024 & 0.0001 \\
\hline D. carota & 0.001 & 0.163 & 0.081 & 1.011 & 0.260 & 0.282 & 1.798 & 0.228 & 0.010 \\
\hline P. vulgaris & 0.001 & 0.096 & 0.114 & 0.794 & 0.347 & 0.515 & 1.867 & 0.179 & 0.017 \\
\hline A. сера & 0.0002 & 0.012 & 0.016 & 0.122 & 0.110 & 0.034 & 0.294 & 0.028 & 0.001 \\
\hline S. tuberosum & 0.001 & 0.076 & 0.070 & 0.273 & 0.234 & 0.126 & 0.781 & 0.062 & 0.004 \\
\hline L. culinaris & 0.0002 & 0.043 & 0.024 & 1.250 & 0.030 & 0.039 & 1.385 & 0.281 & 0.001 \\
\hline
\end{tabular}

*Assuming 50\% inorganic As present in vegetables for produce carcinogenic risk (Saha and Zaman, 2013) 
Conclusion

The results from the sequential extraction procedures revealed that $\mathrm{Cr}, \mathrm{Ni}, \mathrm{Cu}, \mathrm{As}, \mathrm{Cd}$ and $\mathrm{Pb}$ in soils were mainly associated with residual fraction followed by the organic matter bound fractions. Vegetables grown in the nearby sites were also contaminated by the relevant metals, especially $\mathrm{As}, \mathrm{Cd}$ and $\mathrm{Pb}$, which could be a potential health concern to the local residents. Most of the metals from dietary intake of vegetables were higher than the maximum tolerable daily intake (MTDI), suggesting a considerable risk. Since, the transfer of metals from soil to vegetables, $\mathrm{Cu}$ and $\mathrm{Ni}$ were indicated to have higher TF values than other metals. THQ revealed that the consumption of studied vegetables species can result in adverse non-carcinogenic health risks to the consumers. The results also elucidated that the concentrations of $\mathrm{As}$ and $\mathrm{Pb}$ in vegetables species might exert lifetime cancer risks in the consumers. The findings of this study significantly contribute to the field of food safety, considering the health risk for Bangladeshi population as it represents the composite samples of highly consumed vegetables, grown and consumed in the country.

\section{ACKNOWLEDGEMENTS}

The authors thank the authority of Patuakhali Science and Technology University (PSTU), Bangladesh and Yokohama National University, Japan for providing laboratory facilities to analyze samples. Furthermore, we are thankful for the kind help from the members of the department of Soil Science Patuakhali Science and Technology University (PSTU), Bangladesh during the field sampling.

Open Access: This is open access article distributed under the terms of the Creative Commons Attribution License, which permits unrestricted use, distribution, and reproduction in any medium, provided the original author(s) and the source are credited.

\section{REFERENCES}

Acosta, J.A., Faz, A., Martínez-Martínez, S. and Arocenac, J.M. (2011). Enrichment of metals in soils subjected to different land uses in a typical Mediterranean environment (Murcia City, Southeast Spain). Applied Geochemistry, 26(3): 405-414, https://doi.org/10.1016/ j.apgeochem.2011.01.023

Ahmad, J.U. and Goni, M.A. (2010). Heavy metal contamination in water, soil, and vegetables of the industrial areas in Dhaka, Bangladesh. Environmental Monitoring and Assessment, 166: 347-357, https://doi.org/10.1007/ s10661-009-1006-6

Ali, M.H.H. and Al-Qahtani, K.M. (2012). Assessment of some heavy metals in vegetables, cereals and fruits in Saudi Arabian markets. Egyptian Journal of Aquatic Research, 38 (1): 31-37, https://doi.org/10.1016/j.ejar.2012.08.002

Bhagure, G.R. and Mirgane, S.R. (2011). Heavy metal concentra- tions in groundwater and soils of thane region of Maharashtra, India. Environmental Monitoring and Assessment, 173: 643-652, https://doi.org/10.1007/ s10661-010-1412-9

CCME (Canadian Council of Ministers of the Environment). (2003). Canadian Environmental Quality Guidelines.

Cui, Y.L., Zhu, Y.G., Zhai, R.H., Chen, D.Y., Huang, Y.Z., Qiu, Y. and Liang, J.Z. (2004). Transfer of metals from soil to vegetables in an area near a smelter in Nanning, China. Environment International, 30(6): 785-91, https:// doi.org/10.1016/j.envint.2004.01.003

DEP (Department of Environmental Protection). (2003). Assessment levels for soil, sediment and water contaminated sites management series. Perth's, Australia.

EFSA. (2006). Tolerable Upper Intake Levels for vitamins and minerals", European Food Safety Authority, Parma, Italy.

FAO. (2006). Arsenic Contamination of Irrigation Water, Soil and Crops in Bangladesh: Risk Implications for Sustainable Agriculture and Food Safety in Asia", FAO Regional Office for Asia and the Pacific, Bangkok, Thailand.

FAO/WHO. (2011). Joint FAO/WHO Food Standards programme Codex committee on contaminants in foods Food. CF/5 INF/1. pp. 1-89.

HIES (Household Income and Expenditure Survey). (2011). Preliminary Report on Household Income and Expenditure Survey-2010. Bangladesh Bureau of Statistics, Statistics Division, Ministry of Planning, Dhaka, Bangladesh.

Hossain, M.Z., Ullah, S.M., Ahad, S.A. and Ullah, M.B. (2007). Transfer of cadmium from soil to vegetable crops. Bangladesh Journal of Scientific and Industrial Research, 42: 327-334, http://citeseerx.ist.psu.edu/viewdoc/download? doi=10.1.1.626.6585\&rep=rep1\&type=pdf

Islam, M.S., Ahmed, M.K. and Al-Mamun, M.H. (2014a). Determination of heavy metals in fish and vegetables in Bangladesh and health implications. Human and Ecological Risk Assessment: An International Journal, 21(4): 986-1006, https://doi.org/10.1080/10807039.2014.950172

Islam, M.S., Ahmed, M.K. and Al-Mamun, M.H. (2015). Metal speciation in soil and health risk due to vegetables consumption in Bangladesh. Environmental Monitoring and Assessment, 187: 288-303, https://doi.org/10.1007/ s10661-015-4533-3

Islam, M.S., Ahmed, M.K., Al-Mamun, M.H. and Hoque, M.F. (2014b). Preliminary assessment of heavy metal contamination in surface sediments from a river in Bangladesh. Environmental Earth Sciences, 73(4): 1837-1848, https:// doi.org/10.1007/s12665-014-3538-5

Islam, M.S., Ahmed, M.K. and Al-Mamun, M.H. (2016). Human exposure of hazardous elements from different urban soils in Bangladesh. Advances in Environmental Research, 2: 79-94.

JECFA. (2000). Evaluation of certain food additives and contaminants. Fifty-third report of the joint FAO/WHO Expert Committee on Food Additives. WHO technical report series, No. 896, World Health Organization, Geneva, Switzerland. 
Kabata-Pendias. (2001). Trace elements in soils and plants (3rd ed.), CRC Press, Boca Raton, FL.

Kashem, M.A. and Singh, B.R. (1999). Heavy metal contamination of soil and vegetation in the vicinity of industries in Bangladesh. Water Air and Soil Pollution, 115: 347-361, https://doi.org/10.1023/A:1005193207319

Kashem, M.A., Singh, B.R. and Shigenao, K. (2007). Mobility and distribution of cadmium, nickel and zinc in contaminated soil profiles from Bangladesh. Nutrient Cycling in Agroecosystems, 77(2): 187-198, https://doi.org/10.1007/s10705006-9056-4

Khan, S., Rehman, S., Khan, A.Z., Khan, M.A. and Shah, M.T. (2010). Soil and vegetables enrichment with heavy metals from geological sources in Gilgit, Northern Pakistan. Ecotoxicology and Environmental Safety, 73(7): 1820-1827, https://doi.org/10.1016/j.ecoenv.2010.08.016

Lei, M., Zhang, Y., Khan, S., Qin, P.F. and Liao, B.H. (2010). Pollution, fractionation and mobility of $\mathrm{Pb}, \mathrm{Cd}, \mathrm{Cu}$, and $\mathrm{Zn}$ in garden and paddy soils from a $\mathrm{Pb} / \mathrm{Zn}$ mining area. Environmental Monitoring and Assessment, 168(1-4): 215222, https://doi.org/10.1007/s10661-009-1105-4

Li, Q.S., Chen, Y., Fu, H., Cui, Z., Shi, L., Wang, L. and Liu, Z.F. (2012). Health risk of heavy metals in food crops grown on reclaimed tidal flat soil in the Pearl River Estuary, China. Journal of Hazardous Materials, 227-228: 148-154, https:// doi.org/10.1016/j.jhazmat.2012.05.023

Luo, C., Liu, C., Wang, Y., Liu, X., Li, F., Zhang, G. and Li, X. (2011). Heavy metal contamination in soils and vegetables near an e-waste processing site, south China. Journal of Hazardous Materials, 186(1): 481-490, https://doi.org/10.1016/ j.jhazmat.2010.11.024

Morillo, J., Usero, J. and Gracia, I. (2004). Heavy metal distribution in marine sediments from the southwest coast of Spain. Chemosphere, 55(3): 431-442, https:// doi.org/10.1016/j.chemosphere.2003.10.047

Peris, M., Carolina, M., Luis, R., Sánchez, R. and Sánchez, J. (2007). Heavy metal contents in horticultural crops of a representative area of the European Mediterranean Region. Science of the Total Environment, 378(1-2): 42-48, https://doi.org/10.1016/j.scitotenv.2007.01.030

Radha, R., Tripathi, R.M., Kumar, A.V., Sathe. A.P., Khandekar, R.N. and Nambi, K.S.V. (1997). Assessment of Pb, Cd, Cu and Zn exposures of 10 year old children in Mumbai. Environmental Research, 80(3): 215-221, https://doi.org/10.1006/ enrs.1998.3919

Rahman, M.M., Asaduzzaman, M. and Naidu, R. (2013). Consumption of arsenic and other elements from vegetables and drinking water from an arseniccontaminated area of Bangladesh. Journal of Hazardous Materials, 262: 1056-1063, https://doi.org/ 10.1016/ j.jhazmat.2012.06.045

Rattan, R.K., Datta, S.P., Chhonkar, P.K., Suribabu, K. and Singh, A.K. (2005). Long-term impact of irrigation with sewage effluents on heavy metal content in soils, crops and ground water-a case study. Agriculture, Ecosystems \& Environment,
109(3-4): 310-322, https://doi.org/10.1016/j.agee. 2005.02.025

RDA. (1989). Recommended Dietary Allowance, $10^{\text {th }}$ ed", National Academic Press, Washington, DC.

Rieuwerts, J.S., Ashnore, M.R., Farago, M.E. and Thornton, I. (2006). The influence of soil characteristics on the extractability of $\mathrm{Cd}, \mathrm{Pb}$ and $\mathrm{Zn}$ in upland and moorland soils. Science of the Total Environment, 366(2-3): 864-875, https://doi.org/10.1016/j.scitotenv.2005.08.023

Saha, N. and Zaman, M.R. (2013). Evaluation of possible health risks of heavy metals by consumption of foodstuffs available in the central market of Rajshahi City, Bangladesh. Environmental Monitoring and Assessment, 185: 38673878, https://doi.org/10.1007/s10661-012-2835-2

Santos, E.E., Lauri, D.C. and Silveira, P.C.L. (2004). Assessment of daily intake of trace elements due to consumption of foodstuffs by adult inhabitants of Rio de Janeiro city. Science of the Total Environment, 327(1-3): 69-79, https:// doi.org/10.1016/j.scitotenv.2004.01.016

Shaheen, N., Irfan, N.M., Khan, I.N., Islam, S., Islam, M.S. and Ahmed, M.K. (2016). Presence of heavy metals in fruits and vegetables: Health risk implications in Bangladesh. Chemosphere, 152: 431-438, https://doi.org/10.1016/ j.chemosphere.2016.02.060

Szolnoki, Z. and Farsang, A. (2013). Evaluation of metal mobility and bioaccessibility in soils of urban vegetable gardens using sequential extraction. Water Air and Soil Pollution, 224: 1737-1752, https://doi.org/10.1007/s11270-0131737-4

Tessier, A. and Campbell, F.G.C. (1987). Partitioning of uace metals in sediments: relationships with bioavailability. Hydrobiology, 149: 43-52.

Tessier, A., Campbell, P.G.C. and Bisson, M. (1979). Sequential extraction procedures for the speciation of particulate trace metals. Analytical Chemistry, 51: 844-851.

Tiwari, K.K., Singh, N.K., Patel, M.P., Tiwari, M.R. and Rai, U.N. (2011). Metal contamination of soil and translocation in vegetables growing under industrial wastewater irrigated agricultural field of Vadodara, Gujarat, India. Ecotoxicology and Environmental Safety, 74(6): 1670-1677, https:// doi.org/10.1016/j.ecoenv.2011.04.029

Tokalıoglu, Ş. and Kartal, S. (2006). Multivariate analysis of the data and speciation of heavy metals in street dust samples from the organized industrial district in Kayseri (Turkey). Atmospheric Environment, 40(16): 2797-2805, https:// doi.org/10.1016/j.atmosenv.2006.01.019

USEPA. (1989). Risk assessment guidance for superfund, Vol. I: Human Health Evaluation Manual. EPA/540/1-89/002. Washington, D.C: Office of Soild Waste and Emergency Response.

USEPA. (2006). USEPA Region III Risk-Based Concentration Table: Technical Back- ground Information", Unites States Environmental Protection Agency, Washington.

USEPA. (2010). Risk-Based Concentration Table. Available at: http://www.epa.gov/reg3hwmd/risk/human/index.htm 
Uzu, G., Jean-Jacques, S., Armelle, B.S., Michael, R., Magdalena, S.S.H., Stéphanie, V., Karine, T., Sébastien, D., Philippe, P. and Camille, D. (2011). In vitro assessment of the pulmonary toxicity and gastric availability of lead-rich particles from a lead recycling plant. Environmental Science \& Technology, 45: 7888-7895, https://doi.org/10.1021/es200374c

VROM (Volkshuisvesting, Ruimtelijke Ordening enMilieubeheer). (2000). Circular on target values and intervention values for soil remediation. Spatial Planning and Environment, Netherlands: Ministry of Housing.

Wang, W.H., Wong, M.H., Leharne, S. and Fisher, B. (1998). Fractionation and biotoxicity of heavy metals in urban dusts collected from Hong Kong and London. Environmental Geochemistry and Health, 20(4): 185-198, https:// doi.org/10.1023/A:1006530300522
WHO. (1985). Guidelines for the Study of Dietary Intakes of Chemical Contaminants", Pp 1-100. WHO Offset Publication No. 87, Geneva, Switzerland.

WHO. (1996). Guidelines for Drinking-Water Quality", 2nd Edn., Vol. 2, World Health Organization, Geneva, Switzerland.

Wong, S.C., Li, X.D., Zhang, G., Qi, S.H. and Min, Y.S. (2002). Heavy metals in agricultural soils of the Pearl River Delta, South China. Environmental Pollution, 119(1): 33-44, https://doi.org/10.1016/S0269-7491(01)00325-6

Xu, D., Zhou, P., Zhan, J., Gao, Y., Dou, C. and Sun, Q. (2013). Assessment of trace metal bioavailability in garden soils and health risks via consumption of vegetables in the vicinity of Tongling mining area, China. Ecotoxicology and Environmental Safety, 90: 103-111, https:// doi.org/10.1016/j.ecoenv.2012.12.018 